Proceedings of the Creative Construction Conference (2018)

Edited by: Miroslaw J. Skibniewski \& Miklos Hajdu

DOI 10.3311/CCC2018-060

Creative Construction Conference 2018, CCC 2018, 30 June - 3 July 2018, Ljubljana, Slovenia

\title{
Enhancing Lean Concept in precast concrete manufacturing with advanced Material Requirements Planning System
}

\author{
Aleksander K. Nicał* \\ Warsaw University of Technology, Ul. Lecha Kaczyńskiego 16, 00-637 Warsaw, Poland
}

\begin{abstract}
Companies operating in the construction industry, like many other companies in the manufacturing industries, in order to maintain their position on the global market, optimize inventories and the production processes. The need to minimize costs and maximize profits from manufacturing, while maintaining a high quality of products means that the "Lean manufacturing" concept must be implemented in all departments of the precast concrete production company. Delivery of prefabricated elements to construction sites is currently carried out based on detailed delivery schedules. These conditions mean that the "Just in time manufacturing" methodology is implemented in the precast concrete production companies. The high costs associated with the need to maintain stocks and resulting from the cost of creating the inventory and cost of maintaining the inventory are certainly not without significance. Achieving these goals is not possible only through detailed production planning, accurate cost determination, better use of storage and manufacturing infrastructure and forecasting sales volumes. In this case, considering the current reduction of inventories, accurate determination of delivery times of raw materials and semi-finished products is also important. The purpose of this paper is to present the method of planning material requirements for precast concrete manufacturing plants based on the MRP (Material Requirement Planning) system.
\end{abstract}

(C) 2018 The Authors. Published by Diamond Congress Ltd., Budapest University of Technology and Economics Peer-review under responsibility of the scientific committee of the Creative Construction Conference 2018.

Keywords: construction industry, lean concept, material requirements planning, precast production

\section{Introduction}

Low productivity, inefficient use of machine and labor resources as well as excessive stocks are not new concerns in the construction industry. Already in the 1970s, the issues of productivity in the construction industry have been widely studied [7]. In the 1980s the research on improving production efficiency was continued [5] among others the impact of labor on production efficiency was analyzed [18], productivity in the construction sector was measured [19] and the field of Productivity Engineering and Management was intensively developed [8]. This decade is also the further implementation of the Japanese "Just-in-Time" concept, started by the Toyota Motor Corporation in the early 1950s [21] that is a management philosophy which enables to integrate and streamline the manufacturing system into its simplest possible processes [11]. The effective implementation of JIT has the benefits of reduced inventory levels, improved employee levels, improved employee morale, improved performance and profitability [10]. The effective implementation of JIT results in benefits in terms of reduced inventory levels, improved employee improvement, and improvement in productivity and profitability [11]. Over the following years, there was also an intense progress in the field of computer techniques, which contributed to the development of many models 
supporting the production processes of precast concrete products, such as the Artificial Intelligence Planner (AIP) [17]. AIP is capable of two functionalities. The first is a data integration system that encourages the automation in the planning process [17]. Current research trends in the field of precast production focus on optimization with the use of genetic algorithms of total production costs while meeting internal resource constraints and the construction site demands for precast elements [16]. Additionally, when developing optimization models, distribution costs, holding and backorder are minimized. For this purpose, among others, genetic algorithms (GAs) for optimizing novel mathematical models, Just-in-Time logistics and each-cycle lengths (JIT-L) were used [15].

Practice shows that in industrial plants producing large-scale pre-cast concrete units, it is necessary to implement integrated systems supporting the quick decision-making process in the field of order planning. However, there are many small production plants on the construction market, for which the costs of implementing such systems are too high. In addition, the number of components necessary for assembly in the production of precast concrete products is much smaller than, for example, in the automotive industry, thus making entire processes less complicated. Considering the above, there is a need to develop transparent systems adapted to support orders for products with a structure consisting of a small number of levels.

\section{Material Requirements Planning System}

The MRP system (Material Requirements Planning) is a supporting tool managing inventory and enabling the creation of plans for the supply of materials and raw materials necessary for production demands [13], [3].

The main objective of the system is to ensure an adequate amount of raw materials and materials necessary to carry out the planned production and supply to the customer, maintain the lowest possible level of inventory and support the planning policy of the enterprise related to the creation of delivery schedules and assembly operations. The basis for the MRP's functioning is to determine the material needs in the assumed time periods, which are the translation of the overarching production plan for orders of elements and subassemblies that are part of the structure of a given product.

The material requirements planning system is based on the following three sets of information:

- main production schedule,

- product structure collection,

- the main set of stocks.

The association of the listed sets with the MRP system is presented in Figure 1.

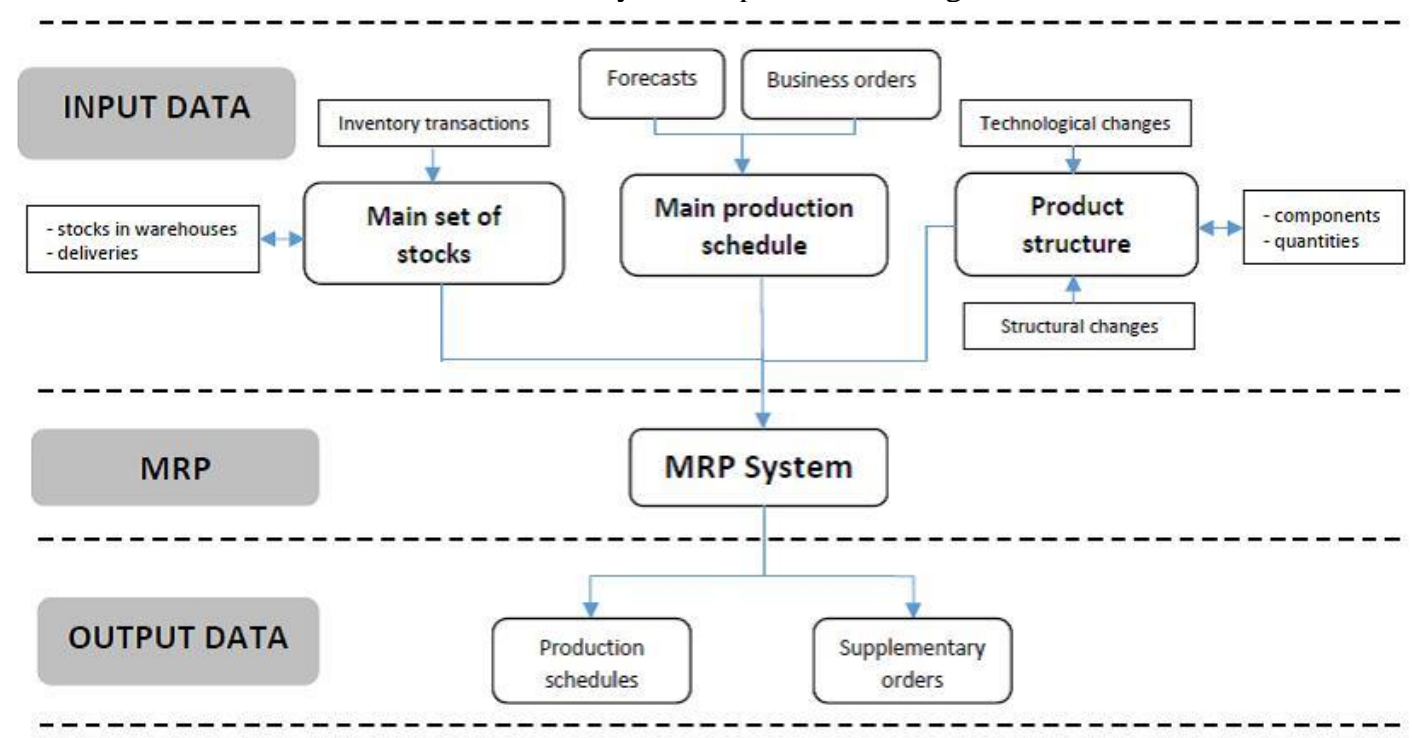

Fig. 1. MRP system information sets and streams - on the basis of [4]. 
The basic data are the duration of certain processes, in particular periods of execution of the desired parts (subassemblies, assemblies) by a "lower" (delivery) production site, or execution of orders directed to external suppliers [4].

A key aspect when planning material requirements is knowledge of the main production schedule, the main set of stocks and product structure. The process of choosing the suitable date of the order must be followed by backplanning, taking into account the moment of placing the order, delivery time to the warehouse and preparation for assembly. In addition, an ongoing monitoring of the level of stocks in warehouses and deliveries needs to be carried out. The structure of the manufactured products and in particular its complexity, expressed in the number of levels and elements forming the structure, also has an impact.

\section{Adopting MRP into precast concrete plants}

The implementation of the MRP system for precast concrete plants requires analyzing the specificity of the construction industry and construction products in terms of technology and organization. Not without significance are also aspects of risks occurring in precast concrete manufacturing [1]. Precast production plants are generally not automated to a large extent as production plants from other industries, such as, for example, electrical engineering, automotive, and pharmaceutical. There is still a large interest in concrete prefabrication on the market [10] and precast fabrication still strongly depends on labor [6]. In addition, orders are implemented primarily for construction companies, which are carrying out construction contracts based on detailed construction schedules, mostly including high contractual penalties for any delay [9]. Thus, it is necessary to produce an element for a specific project and within a strictly defined period. Therefore, orders should be made according to the Just-in-Time methodology. Another factor influencing the development of the MRP system is the seasonality of construction in many countries and the resulting variability in orders over the year. The winter period is usually associated with a reduction of construction works, which directly affects the production assumptions, and, above all, the strategy of resource procurement. Skipping this in combination with inaccurate planning methods, inefficient resource utilization often affect overstocking in the precast industry [20], [14].

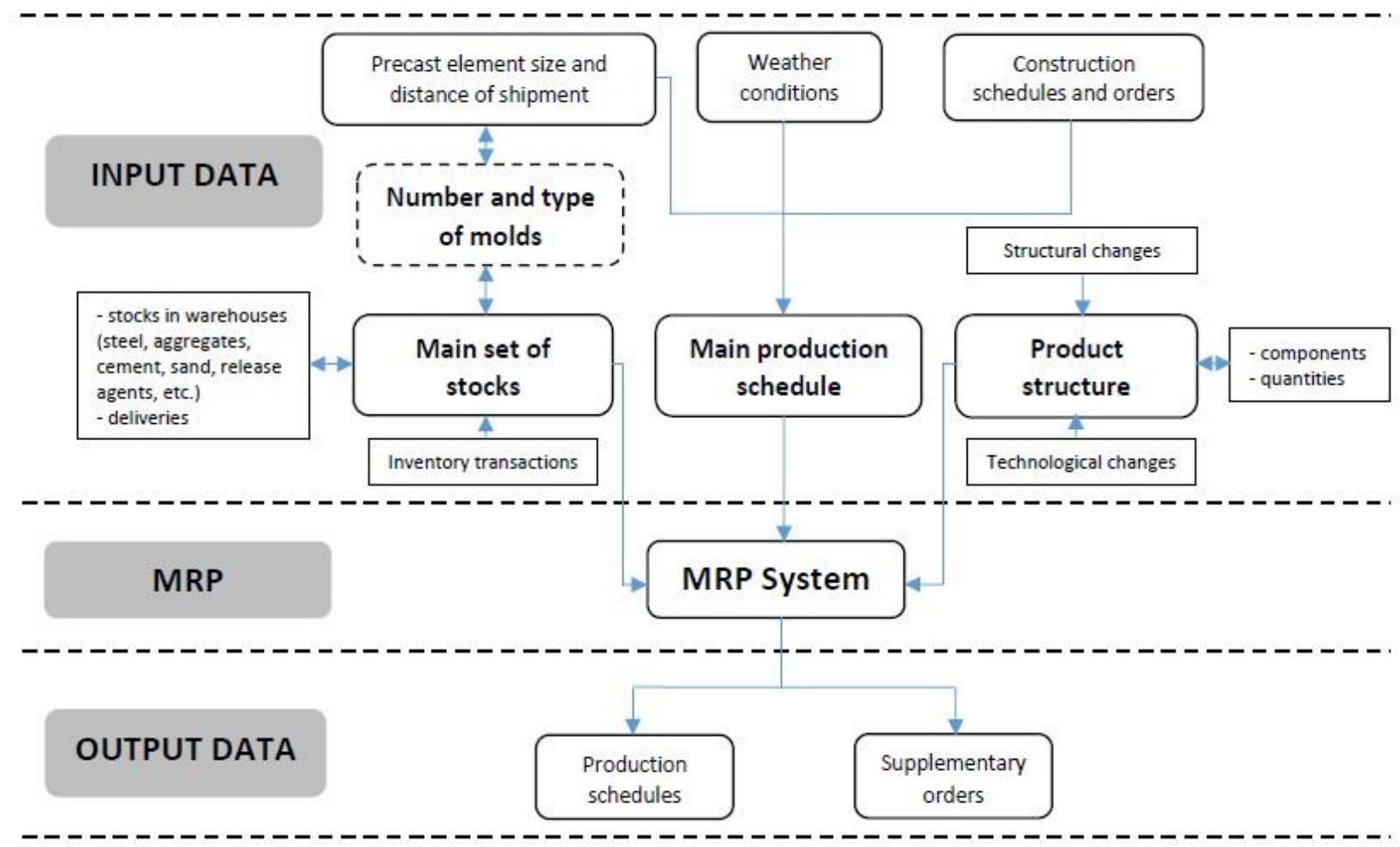

Fig. 2. MRP system for precast concrete plants. 
It is also worth emphasizing the circumstance related to the securing of resources (aggregate, cement) by the impact of weather conditions in winter, causing the need to invest in the appropriate infrastructure to handle these resources (thermally insulated silos and tanks). Moreover, a lower temperature in the production hall may affect technological processes, e.g. the need for longer curing processing of concrete or increase costs, e.g. through the need to use concrete admixtures or heaters. Precast concrete elements do not have such a complex structure as, for example, electronic machines or devices. They require, however, the use of a large number of steel molds [12], which largely determines the production capacity. The molds constitute the production resource of the plant. Considering the high purchase cost of the molds, their use in the production processes should be maximized, on the one hand. On the other hand, a wide and diverse range of orders makes it necessary to use steel molds adapted to be retooled [2]. Such an approach makes it possible to reduce the number of molds and costs, however, it slows down the production process and makes it necessary to organize additional space in the plant for their retooling. The difficulties in shipping of precast elements are also not without significance, which due to their large size and mass require over-standard transport means and often additional time. The MRP system for the production of precast concrete elements is presented in Figure 2.

In order to illustrate the operation of the MRP system below, an example production of two different types of railway sleepers marked as A and B is presented. The product structure is shown in Figure 3.
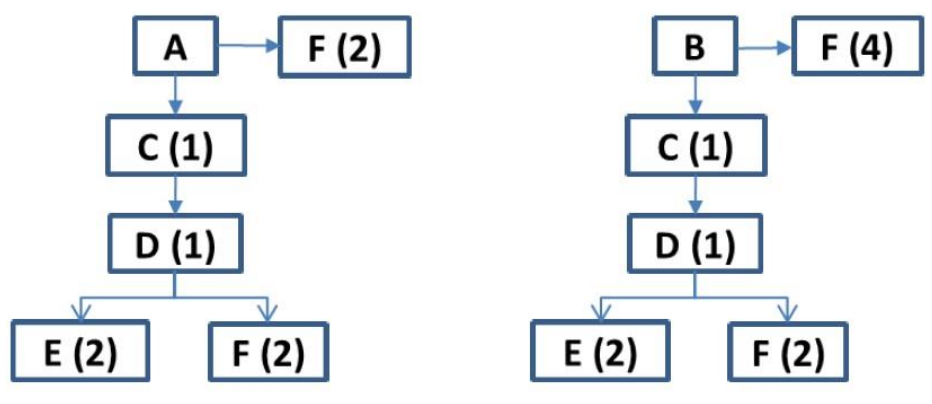

Fig. 3. Structure of prefabricated railway sleeper type I (A) and type II (B) - examples.

Letters denote further levels in the product structure that are:

A - railway sleeper type I,

$\mathrm{B}$ - railway sleeper type II,

C - mold equipped with reinforcement basket,

$\mathrm{D}$ - reinforcement basket,

E - reinforcing steel,

F - steel accessories (fastening screws, nuts, rings, dowels, etc.).

The number of given elements, in this case, they are sets of the assortment described above, included in the position performed at a higher level is indicated in brackets. On day 7 and 11, the production of A and B railway sleepers was planned. The main production schedule, stocks at the end of the first day and delivery periods are presented in Table 1.

Table 1. Main production schedule, stocks at the end of the first day and delivery periods.

\begin{tabular}{|c|c|c|c|c|c|c|c|}
\hline \multirow{2}{*}{$\begin{array}{l}\text { Product, } \\
\text { subassembly, } \\
\text { part }\end{array}$} & \multicolumn{5}{|c|}{ Day } & \multirow{2}{*}{$\begin{array}{l}\text { Stock at the end of } \\
\text { the first day }\end{array}$} & \multirow{2}{*}{$\begin{array}{l}\text { Delivery period (in } \\
\text { days) }\end{array}$} \\
\hline & 7 & 8 & 9 & 10 & 11 & & \\
\hline A & 660 & - & - & - & 560 & 60 & 2 \\
\hline B & 480 & - & - & - & 490 & 80 & 2 \\
\hline $\mathrm{C}$ & - & - & - & - & - & 20 & 1 \\
\hline D & - & - & - & - & - & 30 & 1 \\
\hline $\mathrm{E}$ & - & - & - & - & - & 40 & 1 \\
\hline $\mathrm{F}$ & - & - & - & - & - & 50 & 1 \\
\hline
\end{tabular}


The production and delivery schedule resulting from the MRP system is presented in Table 2. In the case of A and B products, the order includes the supply of an appropriate amount of aggregate, sand, cement, and additives needed to produce a concrete mix for both types of railway sleepers.

Table 2. Production and delivery schedule for products A and B, subassemblies C and D and parts E and F.

\begin{tabular}{|c|c|c|c|c|c|c|c|c|c|c|c|c|}
\hline \multirow{2}{*}{$\begin{array}{l}\text { Product, } \\
\text { subassembly, } \\
\text { part }\end{array}$} & \multirow{2}{*}{ Specification } & \multicolumn{10}{|c|}{ Day } & \multirow{2}{*}{$\begin{array}{l}\text { Delivery period } \\
\text { (in days) }\end{array}$} \\
\hline & & 2 & 3 & 4 & 5 & 6 & 7 & 8 & 9 & 10 & 11 & \\
\hline \multirow{5}{*}{ A } & Gross demand & & & & & & 660 & & & & 560 & \\
\hline & Stock & & & & & & 60 & & & & & \\
\hline & Net demand & & & & & & 600 & & & & & 2 \\
\hline & Supply & & & & & & 600 & & & & & \\
\hline & Order & & & & 600 & & & & & & & \\
\hline \multirow{5}{*}{ B } & Gross demand & & & & & & 480 & & & & 490 & \\
\hline & Stock & & & & & & 80 & & & & & \\
\hline & Net demand & & & & & & 400 & & & & & 2 \\
\hline & Supply & & & & & & 400 & & & & & \\
\hline & Order & & & & 400 & & & & & & & \\
\hline \multirow{5}{*}{$\mathrm{C}$} & Gross demand & & & & 1000 & & & & & & & \\
\hline & Stock & & & & 20 & & & & & & & \\
\hline & Net demand & & & & 980 & & & & & & & 1 \\
\hline & Supply & & & & 980 & & & & & & & \\
\hline & Order & & & 980 & & & & & & & & \\
\hline \multirow{5}{*}{$\mathrm{D}$} & Gross demand & & & 980 & & & & & & & & \\
\hline & Stock & & & 30 & & & & & & & & \\
\hline & Net demand & & & 950 & & & & & & & & 1 \\
\hline & Supply & & & 950 & & & & & & & & \\
\hline & Order & & 950 & & & & & & & & & \\
\hline \multirow{5}{*}{ E } & Gross demand & & 1900 & & & & & & & & & \\
\hline & Stock & & 40 & & & & & & & & & \\
\hline & Net demand & & 1860 & & & & & & & & & 1 \\
\hline & Supply & & 1860 & & & & & & & & & \\
\hline & Order & 1860 & & & & & & & & & & \\
\hline \multirow{5}{*}{$\mathrm{F}$} & Gross demand & & 1900 & & 2800 & & & & & & & \\
\hline & Stock & & 50 & & & & & & & & & \\
\hline & Net demand & & 1850 & & 2800 & & & & & & & 1 \\
\hline & Supply & & 1850 & & 2800 & & & & & & & \\
\hline & Order & 1850 & & 2800 & & & & & & & & \\
\hline
\end{tabular}

\section{MRP system in Lean Concept}

The use of the MRP system contributes to reducing the costs of storing stocks related to the supply of raw materials and "on time" production in accordance with the main schedule production. The system also allows the elimination of unnecessary stocks, contributes to timely production, improves flexibility in terms of order fulfillment. Other advantages include creating the basis for long-term planning, which positively affects the development of a company, its usefulness in the case of batch production or the implementation of product assembly processes, and the ease of coordinating ordering processes throughout the enterprise. The MRP system fits very well into the "Just-inTime" concept and also intends to integrate the procurement processes between construction sites and precast concrete plants. Accurate planning of orders and deliveries is also a great advantage for construction companies, as it facilitates the development of schedules and the implementation of construction contracts based on them.

The MRP system also has disadvantages, including the need to use high-quality computer equipment, in particular when there is a very large number of orders, and the structural complexity of products is considerable. It should be emphasized, however, that unlike many other industries, construction production is characterized by a relatively small complexity of products. In addition, a large part of the manufactured products is not in full readiness, which means the transfer of many activities to construction sites, for example, the on-site installation of window and door frames in prefabricated wall elements. Other potential disadvantages include the risk of increasing the costs of placing orders and transport resulting from the reduction of stocks. At this point, however, it should be noted that the increase in the volume of stocks in construction significantly affects their cost. In particular, taking into account the storage method of, for example, cement and aggregates in the period of precipitation and winter. One should also remember about the high sensitivity to periodical fluctuations in demand, which in construction depends on the general macroeconomic conditions of the economy and the season. 


\section{Conclusions}

The MRP system is a very useful tool when planning orders and deliveries as well as production scheduling. The presented example of MRP system functioning in the production of concrete railway sleepers is not very complex and it should be noted that as a result it well illustrates the idea of the system. When increasing the diversity of the product range and the resulting increased number of components, semi-finished products, and parts, the system requires the support of advanced computer techniques. Further research in this area will lead to the development of systems reducing the participation of people in the area of the active planning of processes and control of production activities while contributing to the reduction of the risk of errors. The aim is to develop precast concrete systems based on dynamic scheduling and resource management for production plants. These systems will also accurately measure the time of tasks performed at the production site, control all employees throughout the shift, collect feedback on the production process, manage internal transport and quality control process, estimate the time required to finish new orders, manage warehouse employees as well as enable allocation of costs of production at any moment of a process, in order to maximize production and financial efficiency.

\section{References}

[1] A. Nicał, Analiza wybranych ryzyk przy produkcji prefabrykatów betonowych, Logistyka, 2015, pp. 3479-3486.

[2] A. Nicał, A. Foremny, K. Kaczorek, P. Kluczuk, Selected innovative solutions and overview of molds for precast concrete, Creative Construction 2015 Conference Proceedings, 2015, pp. 128-133.

[3] C. Bozarth, R.B. Handfield, Wprowadzenie do zarządzania operacjami i łańcuchem dostaw, HELION, Gliwice, 2007.

[4] C. Skowronek, Z. Sarjusz-Wolski, Logistyka w przedsiębiorstwie, PWE, Warszawa, 2012.

[5] C.H. Oglesby, H.W. Parker, G.A. Howell, Productivity Improvement in Construction, McGraw-Hill, New York, 1989.

[6] Chien-Ho Ko, Shu-Fan Wang, Precast production scheduling using multi-objective genetic algorithms, Expert Systems with Applications, 2011, pp. 8293-8302.

[7] D. Bishop, Productivity in the Construction Industry in Turin D A (ed), Aspects of the Economics of Construction, Godwin, London, 1975, pp. 58-96.

[8] D.J. Sumanth, Productivity Engineering and Management, McGraw-Hill, 1984.

[9] E. Radziszewska-Zielina, B. Sroka, Selection of the Order of the Construction of Structures of a Multiple-Structure Project, Taking Into Account Time-Cost Optimisation, ICMESD 2017, ASME PRESS, New York 2017, pp. 167-177.

[10] G. Adamczewski, A. Nicał, Wielkowymiarowe prefabrykowane elementy z betonu, Inżynier Budownictwa, 2012, pp. 46-53.

[11] L.S. Pheng, R.Y. M. Chan, The Application of Just-in-Time Principles to Process Layout for Precast Concrete Production, Singapore Management Review, 1996, pp. 23-40.

[12] M. West, Flexible fabric molds for precast trusses. Concrete Precasting Plant and Technology, 2006, pp. 46-52.

[13] M. Zięba, J. Ziółkowski, System planowania potrzeb materiałowych (MRP) w przedsiębiorstwie produkcyjnym, Biuletyn WAT, Vol. LXI (3), 2012, pp. 353-364.

[14] N.N. Dawood, Knowledge elicitation and dynamic scheduling using a simulation model: An application to the precast manufacturing process. Proceedings of the Civil-Comp93, Part 4: Knowledge based systems for civil and structural engineering, 1993.

[15] S.A. Ghasimi, R. Ramli, N. Saibani, A genetic algorithm for optimizing defective goods supply chain costs using JIT logistics and each-cycle lengths, Applied Mathematical Modelling, Vol. 38 (4), 2014, pp. 1534-1547.

[16] Sherman H.A. Li, H. Ping Tserng, Samuel Y.L Yin, Ching-Wen Hsu, A production modelling with genetic algorithms for a stationary precast supply chain, Expert Systems with Applications, 2010, pp. 8406-8416.

[17] V. Benjaoran, N. Dawood, Intelligence approach to production planning system for bespoke precast concrete products, Automation in Construction, Vol. 15 (6), 2006, pp. 737-745.

[18] W.F. Maloney, Productivity Improvement: The Influence of Labour, Journal of Construction Engineering and Management, Vol 109, No 3, September 1983.

[19] W.H.E. Suite, Measurement of Productivity in the Construction Sector in Proceedings of the Fifth CIB W65 International Symposium on The Organisation and Management of Construction, Vol 2, Productivity and Human Factor in Construction, Lansley P.R. and Harlow D.A. (eds) and F.N. Spon, London, 1987, pp. 856-867.

[20] W.T. Chan, H. Hu, Production scheduling for precast plants using a flow shop sequencing model, Journal of Computing in Civil Engineering, ASCE, 79 (17), 2002, pp. 1605-1616.

[21] Y. Sugimori, F. Kusunoki, F. Cho, S. Uchikawa, Toyota Production System and Kanban Materialisation of Just-in-Time and Respect-forHuman System, International Journal of Production Research, Vol 15, No 6, 1971, pp. 553-564.

[22] http://www.iposystem.com.pl. 